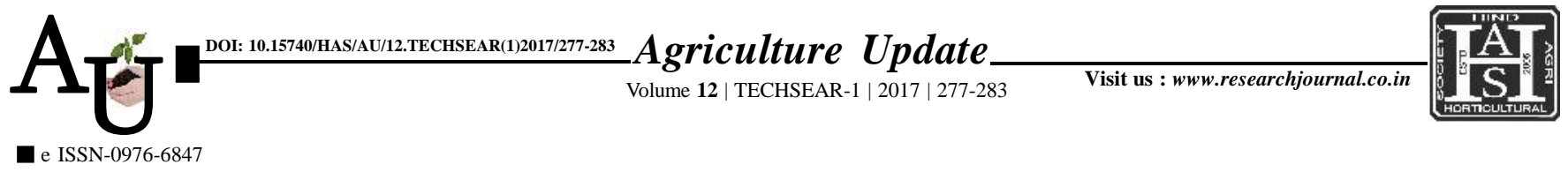

\title{
A Review : \\ Entomopathogenic fungi as potential bio-control agents and mode of action against insect pests
}

\section{C.H. LYDIA, V. SUNIL, K. RENUKA, V. SANDHYA AND J.S. BENTUR}

Article Chronicle: Received :

11.07.2017;

Accepted :

26.07.2017

\section{KEY WoRDS :}

Bio-control agents, Insect pests, Fungi, Whiteflies
SUMMARY : The growing demand for reducing chemical inputs in agriculture and increased resistance to insecticides have provided great impetus to the development of alternative forms of insect-pest control. Biocontrol offers an attractive alternative to the use of chemical pesticides. Entomopathogenic fungi are naturally occurring organisms which are least damaging to the environment. Their mode of action appears little complex which makes it highly unlikely that resistance could be developed to the biopesticide. Past research has shown some promise of the use of fungi as a selective pesticide. The current article updates us about the recent progress in the field of entomopathogenic fungi in biocontrol of insect pests and their possible mechanism of action to further focus on research lacunae in developing them as effective biocontrol agents against insect pests.

How to cite this article : Lydia, C.H., Sunil, V., Renuka, K., Sandhya, V. and Bentur, J.S. (2017). Entomopathogenic fungi as potential bio-control agents and mode of action against insect pests. Agric. Update, 12(TECHSEAR-1) : 277-283; DOI: 10.15740/HAS/AU/12.TECHSEAR(1)2017/277-283.
Author for correspondence :

\section{C.H. LYDIA}

Agri Biotech Fundation, Rajendranagar, HYDERABAD (TELANGANA) INDIA Email:lcyldiach@gmail. com

See end of the article for authors' affiliations 